\title{
Effect of Computer- Simulation on Achievement and Interest in Cell Division Among Male and Female Secondary School Students in Abuja, Nigeria
}

\author{
Dr. M.A. OKOLO \& Dr. O. G.OLUWASEGUN \\ Nasarawa State University, \\ Department of Science, Technology and Mathematics Education, \\ Faculty of Education, Keffi , Nasarawa State.
}

\begin{abstract}
This study is aimed at investigating the 'Effect of Computer Simulation on Achievement and Interest in Cell Division among Male and Female Secondary School Students in Abuja. The study adopted quasi experimental research design. The sample of the study was 72 students consisting of 33 males and 39 females from two intact classes randomly drawn from all the co-educational schools in the six area councils in Abuja. One class was randomly assigned to the experimental group while the other served as the control group.The experimental group was taught cell division using computer simulation teaching strategy while the control group was taught using the conventional teaching method. The study lasted for six weeks. Two research questions were raised and two corresponding null hypotheses were postulated and tested at 0.05 level of significance. Two instruments were used for data collection which were; Cell Division Achievement Test (CDAT) and Cell Division Interest Scale (CDIS). CDIS was based on four point likert rating scale. CDAT had a reliability coefficient of 0.81 using kuder- Richard K-R 21 and CDIS had 0.86 using Cronbach's alpha. The results revealed that: Computer simulation strategy was found to be better than the conventional method in teaching and learning of cell division; gender was not a determinant factor in Biology students' interest ratings in teaching cell division. It was recommended among others that Biology teachers should adapt the use of Computer simulation strategy in teaching cell division.
\end{abstract}

Keywords:- Cell division, Achievement, Interest, Gender, Computer Simulation.

\section{INTRODUCTION}

Biology is the study of plants and animals which partly provides scientific literacy required for national growth; stability and development; the effects of the microbes and how to control them. Biology is a broad field covering the minute working of chemical inside the cells to a broad scale concept of ecosystem and global climate change. It is one of the requirements for studying science related courses in the tertiary institutions. According to Federal Republic of Nigeria (FRN) in the National Policy on Education NPE (2014), learning of Biology will provide the students with suitable laboratory and field skills in Biology, meaningful and relevant knowledge in Biology, scientific knowledge that is applicable in health, agriculture, personal and community daily life matters and development of functional scientific attitudes.

However, despite the importance of Biology, research findings have shown that a number of topics in Biology such as genetics, ecology, mitosis and meiosis (cell division), pose a lot of difficulty for Biology students in some cases even to the Biology teachers (Etobru,2017). Cell from the Latin word 'cella' meaning small room, is the basic structural, functional and biological unit of all known living organism, cell undergoes processes for growth and replication of progeny. These processes are known as Cell division which is fundamentals to life. The dynamic and the chromosomal orientation during the process of the cell division are pertinent to the understanding of the topic.

The WAEC Chief Examiner's report (2013-2017) has continuous distressed highlights on students' weakness in answering questions from some difficult topics which includes cell division. It is good to note that students' performances are not consistent over the years. WAEC Chief Examiners' generals comment reports of means scores and standard deviations for Biology is shown in table 1 below:

\begin{tabular}{|c|c|c|}
\hline Year & Mean scores & Standard deviation \\
\hline 2014 & 29.00 & 12.37 \\
\hline 2015 & 18.00 & 10.49 \\
\hline 2016 & 21.00 & 10.34 \\
\hline 2017 & 31.00 & 11.79 \\
\hline 2018 & 27.00 & 10.34 \\
\hline
\end{tabular}

Table 1: Students' Mean Scores and Standard Deviations in WAEC in Biology (2014-2018)

Source: Statistics Section; West African Examination Council (WAEC) National Office, Lagos, Nigeria.

From table 1, the highest mean score from 2014-2018 is 31.00 , this is not encouraging. It is not only frustrating the efforts of students, education stake holders and parents; It has also made it difficult to have a reasonable number of students' enrolment in related area of studies at tertiary levels. According to Wakesa (2010) cell division is one of the topics ranked near the top of the ladder of difficulty by 
learners and teachers. It has been reported that teachers and learners have misconception on cell division being difficult and it should be avoided or ignored (Etobru, 2017).

Despite the positive roles played by science and technology in general, the teaching and learning of science has suffered setback. Bichi(2017) affirmed that, there is a persistent low level of students' achievement in sciences at the various levels of examinations. Gambari (2014) attested that, students' achievements of core science subjects in which Biology is inclusive at the secondary school level are not encouraging. Various reasons have been attached to this problem by scholars.

Studies have shown that if teaching-learning strategies are improved, achievement and interest can be enhanced (Elvis, 2014; Oluwasegun, 2019). Also, research evidences posited that some science teaching strategies have been identified which have being applied in the teaching and learning in various courses and subjects with promising results. These include; cooperative learning, computer assisted instruction, computer- supported cooperative learning, Computer Simulation (CS), Guided Discovery (GD), Guided inquiry (GI), Problem Based Learning (PBL), scaffolding strategy (Gambari, 2010;Oluwasegun 2019\&Wakesa, 2010). It has been envisaged that the traditional method might not be the best approach to support the understanding of cell division hence a better approach be sort.

Computer simulation is a computer production of a model which is an enriched device in which pictures, sound and motion process are synchronized and projected for effective teaching and learning processes. It can also be defined as an imitation of a thing or process or situation of a model especially for the purpose of learning. This might require a model to be developed, this model represent the key characteristics of the said concept. Computer stimulation can be used in technology atomization, training, education, videos, scientific modelling, natural system, and human system. It plays significant role in stimulating learning among all age groups. According toKuta (2015) in computer stimulation, action is created from a series of images which gives an illusion of something living. It allows students to deal with things in a more realistic way with matters of vital concern.

Conventional or traditional teaching method is the usual method of teaching Biology in secondary schools in Nigeria. Conventional teaching involves the use of text books and lecture teaching methods. King'Aru (2014) stated that in conventional method, there is very little interaction between the teacher and the students or among the students themselves in the classrooms it is mostly teacher dependent and exam orientated. The emphasis is mainly to be able to remember and reproduce facts, principles and theories, computer stimulation strategy on the other hand is student centred.

Computer stimulation is entertaining and motivational because of its dramatic and game like components which makes learning more effective and retention could be better sustained, It reduces difficulty (risk) that accompanies practice with real life situations. It Costs money over traditional teaching methods and requires specialized resources (animators and writers). According to Olele (2008) research findings showed a positive impact on Computer Simulation based teaching and learning methods. This is because of its features that consist of movement and coloring which brings real learning environment into Biology class room. Zamzuri (2007) posited that simulation helps students to learn and understand some learning concepts through the use of visualization. Computer stimulation helps students build their own mental on the observation to be recorded in the form of schemas in their long term memory. Recorded visual is retained in the memory structure for a longer period. Kiboss, Ndirangu and Wakesa (2010) emphasized that the visual forms of learning encourages students to develop an understanding of learnt concepts and support their memory retention which improves their achievement and interest. However, Starbak, Erjavec and Peklaj(2010)who reported that animated simulation do notsignificantly improve the performance ofstudents.

Interest is giving attention or being curious towards something or someone. There can therefore be no meaningful science and technology of a nation with low interest and enrolment rate in the basic foundation of Biology subject in the secondary schools. As Festus and Ekpete (2012) have noted that the attitude of a student are antecedents which serve asstimuli that trigger actions as well as interests. They stressed that interest (both intrinsic and extrinsic) and attitudes of students play substantial roles among pupils studying science.Interestin Education is a powerful tool that could enhances learning, it can be aroused in an individual by an activity that tends to satisfy the individuals needs.

Interest could be demonstrated by showing curiosity, concern and patience towards all challenges accompanying the achievement of the goals especially in the classroom. Such attitudes of science as probing, questioning, experimenting, and logical reasoning can only be developed by an individual himself through providing a conducive atmosphere for him to develop an interest of doing so. It is a clear and indisputable fact that learning and teaching activities including that of sciences are irrelevant if the needs and interests of the students are not considered or met.Adebayo (2016)reported that, there is no significant difference in gender students' interest ratings in their study. Ibe (2013) who investigated effects of guided inquiry and expository on students' performance and interest in biology showed that, female students showed higher interest ratings than the male students however, Gambari (2014) stated that other factors like the teaching strategy, location and individual perception could have made the difference. Therefore, Biology teachers need to present cell division to learners such that their interest will be aroused to enhance higher achievement. Therefore the decision to conduct a research on the Effect of Computer simulation on 
Achievement and Interest on Cell division among Male and Female Secondary Schools Students' in Abuja.

Gender is a division into which an organism is placed according to its reproductive functions or organs. In this context gender is based on students' status of male and female. Findings from researchers such as; Oscar, Luis and Lopez (2018), Abdullahi (2014) stipulates that, there is a general imbalance that exists in gender and in technology base teaching strategies use, access, career and curiosity among students. Abdullahi (2014) stressed that, when there are gender related differences in science, the method of teaching could be the cause. Abdullahi opined that an appreciable way of obtaining optimal achievement is to engage the strategies that are gender bias free. To this end, this study aimed at finding out the Effect of Guided Inquiry on Achievement in Cell Division amongst Male and Female Secondary Schools Students in FCT, Abuja.

\section{OBJECTIVES OF THE STUDY}

The Objectives of the study was to investigate the gender difference in achievement and interest among secondary school students taught cell division using computer simulation instructional technique. specifically the study sought to determine;

1. The effects of computer simulation on achievement in cell division among secondary schools students in Federal Capital Territory, Abuja.

2. The effects of computer simulation on male and female students' interest ratings taught cell division in Federal Capital Territory, Abuja.

\section{Research Questions}

The following research question guided the study;

1. What is the mean difference in achievement scores of students taught cell division using computer simulation and to those taught using conventional method?

2. What is the mean difference in interest ratings of male and female students taught cell division using computer simulation?

\section{Statement of the Hypotheses}

The following null hypotheses were tested at 0.05 levels of significance to guide the study;
$\mathrm{H}_{\mathrm{O} 1}$ There is no significance difference in the mean achievement scores of students taught cell division using Computer Simulation and those taught using Conventionalmethod.

$\mathrm{H}_{\mathrm{O} 2}$ There is no significance difference in male and female students'interest ratingstaught cell division using computer simulation.

\section{Research Design}

The research work adopted quasi-experimental research design involving pre-test and post-test design with one experimental group and one control group. The target population for this study consisted of co-educational senior secondary schools students between the ages of 14-18 years in FCT, Abuja. The sample involved seventy two (72) students; thirty three (33) males and thirty nine (39) females from two intact science classes. Multi-stage random sampling technique was used to select two intact science classes. Simple random sampling was used to select the experimental group and the control group from the two intact classes. Two instruments validated by experts were used for data collection which were; Cell Division Achievement Test (CDAT) and Cell Division Interest Scale (CDIS). CDAT had a reliability coefficient of 0.81 using Kuder-Richard K-R ${ }_{21}$ and CDIS had 0.86 using Cronbach's alpha. These are considered suitable for the study.

\section{DATA ANALYSIS AND RESULTS}

Research Questions were answered using means and standard deviations sand null hypotheses were tested using analysis of covariance (ANCOVA).

\section{Research Question 1.}

What is the mean difference in achievement scores of students taught cell division using computer simulation and to those taught using conventional method?

\section{Null hypothesis 1}

Ho1There is no significance difference in the mean achievement scores of students taught cell division using Computer Simulation and those taught using Conventional method.

\begin{tabular}{|c|c|c|c|c|c|c|}
\hline Source & $\begin{array}{c}\text { Type III Sum of } \\
\text { Squares }\end{array}$ & df & Mean Square & F & Sig. & Partial Eta Squared \\
\hline Corrected Model & 8881.327 & 3 & 2960.442 & 29.637 & .000 & .000 \\
\hline Intercept & 7797.225 & 1 & 7797.225 & 78.058 & .000 & .420 \\
\hline Pre test & 7608.523 & 1 & 7608.523 & 76.169 & .005 & .414 \\
\hline Group & 1095.875 & 2 & 547.937 & 5.485 & & \\
\hline Error & 10788.093 & 108 & 99.890 & & & \\
\hline Total & 448092.000 & 112 & & & & \\
\hline Corrected Total & 19669.420 & 111 & & & & \\
\hline
\end{tabular}

Table 2:- Analysis of Covariance (ANCOVA) of Achievement Scores of Students taught cell division using Computer Simulation and Conventional Method. 
Table 2 shows that $\mathrm{F}_{(2,108)}=5.485, \mathrm{P}=0.005<0.05$ for this study, the null hypotheses of there is no significance difference in the mean achievement scores of students taught cell division using Computer Simulation and those taught using Conventional methodis rejected. The difference is statistically significanttherefore; there is an indication that students in experimental group had higher achievement scores than those in control group.

\section{Research Question 2}

What is the mean difference in interest ratings of male and female students taught cell division using computer simulation?

\section{Null hypotheses 2}

Ho2 There is no significance difference in male and female students 'interest ratings taught cell division using computer simulation.

\begin{tabular}{|c|c|c|c|c|c|c|}
\hline Source & Type III Sum of Squares & Df & Mean Square & F & Sig. & Partial Eta Squared \\
\hline Corrected Model & 71.474 & 2 & 35.737 & 2.349 & .111 & .121 \\
\hline Intercept & 194.233 & 1 & 194.233 & 12.765 & .001 & .273 \\
\hline Pre interest & 44.084 & 1 & 44.084 & 2.897 & .098 & .079 \\
\hline Gender CS & 53.889 & 1 & 53.889 & 3.542 & .068 & .094 \\
\hline Error & 517.337 & 34 & 15.216 & & & \\
\hline Total & 81478.000 & 37 & & & & \\
\hline Corrected Total & 588.811 & 36 & & & & \\
\hline
\end{tabular}

Table 3: Analysis of Covariance (ANCOVA) of male and female students' interest ratings taught cell division using computer simulation;

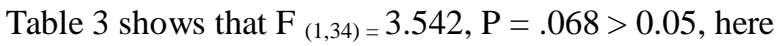
the null hypotheses of there is no significance difference in male and female students'interest ratings taught cell division using computer simulation is retained. Therefore, there is no statistical difference in the interest ratings of male and female students taught cell division using CSP. This indicates that, male and female students developed interest after exposure to experiment; therefore, gender is not a major factor to determine interest after exposure to experiments.

\section{DISCUSSIONS OF FINDINGS}

The finding of the study revealed that, there is a significance difference in the mean achievement scores of students taught cell division using Computer Simulation (CS) and those taught using the conventional method (CM). Students taught cell division using Computer simulation strategy outperformed their counterpart taught using conventional method. This is in line with Zamzuri (2007) and Olele (2008) who carried out investigations on students' achievement using CS and conventional method and found out that, students in CS performed better than those in CM group. Also, Kiboss, Niranju and Wakessa (2010) buttressed this fact in their study and posited that computer simulation enhances students understanding of concepts than the conventional/traditional method of teaching. These results affirm the fact that the use of innovative and activity base teaching strategies such as CS aids students' learning; improves their achievement and enhances their performances. This is because interactive computer simulations.

foster the visualization and active cognitive processing of abstract information due to its feature that combine word, text, pictures and videos in a single frame. However, the finding from the study did not agree with the finding of Starbak, Erjavec and Peklaj (2010) who reported that animated simulation does not significantly improve the performance of students.

The study also revealed that there is no statistical difference in the interest ratings of male and female students taught cell division using computer stimulation programming. This indicates that, male and female students developed interest after exposure to the experiment; therefore, gender is not a factor to determine interest after exposure to computer stimulation. This is in agreement with Adebayo (2016)who reported that, there is no significant difference in gender students' interest ratings in their study. Ibe (2013) who investigated effects of guided inquiry and expository on students' performance and interest in biology showed that, female students showed higher interest ratings than the male students, this is not in agreement with Gambari (2014) and the current study, other factors like the teaching strategy, location and individual perception could have made the difference. Social cultural factors which create gender differences in task accomplishment had no influence in this situation.

\section{RECOMMENDATIONS}

On the basis of the findings of this study, the following recommendations are made;

1. Biology teachers are encouraged to adapt the use of CSP to teach cell division to both single and co educational schools despite the time consuming nature and the financial implication of the instructional strategy.

2. Government and stake holders are encouraged to provide the relevant instructional materials that are required to carry out such instructional strategies.

3. Biology teachers should be trained on how to use computer simulation package to teach cell division. 


\section{REFERENCES}

[1]. Adebayo, A. O. andOladele, O. (2016).Effects Of Computer Simulation Instructional Strategy On Biology Students'Academic Achievement in DNA replication and transcription. Asian Journal of Educational Research, 4(2), 102-106.

[2]. Abdullahi, A. (2014).Instructional Materials and Students Academics Achievements in Physics. IllorinAtoto press. Retrieved from https//www.Research gate net.

[3]. Bichi, S. S. (2017). Impact of Problem Solving and Discovery Strategies on the Academic Performance, Attitude and Retention in Genetics among Secondary Schools ATBU.Journal of Science, Technology and Education, 4(14).

[4]. Elvis, M. G. (2014). Teaching Methods and Students' Academic Performance. International Journalof Humanities and Social Science Invention, 2(9), 2319 7722. Retrieved from https://www.researchgate.net/pu blication/24124430_Teaching_Methods_and_Students $\% 27$ Academic_Performance.

[5]. Etobro, A.B. (2017).Students'Perception of Difficult Subjects in Biology in Secondary Schools, Lagos State Nigeria. Retrieved from https://.www.ajoi.info.PDF

[6]. Festus, C. andEkpete, O.A. (2012).Improving Students and Performance and Attitude towards Chemistry through Problem Solving Teaching. Retrieved from http;//www.resaerchgate.net

[7]. Gambari, A. I. (2014).Improving Senior Secondary Schools Achievement and Retention In Biology through Video-Base Multi- Media Instruction. Retrieved from https://.www research gate.net

[8]. Gambari, A.I. (2010).Effective of Computer Assisted Instruction Package in Cooperatives Settings on Senior Secondary Schools Students' Performance in Physicsin Minna.

[9]. Unpublished Ph.DDissertation, University of Ilorin, Nigeria. Retrieved from https://.www research gate.net

[10]. Kiboss, J., Ndirangu, M. andWakessa., (2006). Effectiveness of Computer Mediated Simulation Program School Biology Pupils Learning Outcomes in Cell Theory.Journal of Science Education Technology, 13(2), 207-213.

[11]. King’Aru, J. M. (2014). Factors Contributing To Poor Performance of Science Subjects: a case secondary schools in Kawe division, Kinondoni municipality. Unpublished master project management dissertation, open university of Tanzania, Tanzania. Retrieved from http://repository.out.ac.tz/598/1/JAMESMUCHWE KING\%E2\%80\%9DARUFinalThesis. pdf

[12]. Kuta, B. (2015). True Elementary Mathematics Worksheet and Games. Retrieved from http://maths geeksmana.com

[13]. Oluwasegun, O. G. (2019).Effectsof Problem Based Learning and Scaffolding Strategies on Achievement And Retention in Waves Among Secondary School Students in Abuja. Unpublished Ph.D thesis, Nasarawa State University, Keffi, Nigeria.
[14]. Olele, C.N. (2008).Emerging Issues Computer Simulation in Schools: A bridge for Digital Divide Phenomenon in Nigeria. Journal of Business and Educational Leadership 3(1).

[15]. Oscar, S and Muigui, N. (2018).Academy Of Motion, Pictures Arts and Sciences. Retrieved from http:www.Oscars.org

[16]. Starbek, P., StarčičErjavec, M., \&Peklaj, C. (2010). Teaching Genetics with Multimedia Results in Better Acquisition of Knowledge and Improvement in Comprehension. Journal of Computer Assisted Learning, 26(3), 214-224.

[17]. WAEC. (2018). Chief Examiners' report on Biology (2014-2018). Retrieved from http://waeconline.org.ng/e-learning/.

[18]. Wekesa, A. (2003). The Effects Of 3D Computer Simulation on Biology Students, Asia pacific form on senior learning and teaching, 15 (2), 16-18.

[19]. Zamzuri, A. (2014). Effect of Various users Control Strategy on Instructional Animation Procedia- Social and Behavioral Sciences 131, 16-19, 2014. 